JOURNAL OF LANGUAGE, LITERATURE, AND TEACHING

Vol. 1 No. 2, August 2019, pp. 42 - 49

Available online at:

STTBADRTA

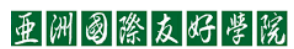

http://www.jllte.stbapia.ac.id

Penggunaan Media Gambar dalam Pembelajaran Kosakata Bahasa Mandarin di SD Perguruan Kristen Methodist Indonesia Pangkalan Berandan 图示教学法对汉语词汇教学的应用调查以火水山卫理学校为例

\author{
Dewi Kartika Tjong \\ STBA-PIA, Medan, Sumatera Utara \\ Dewi Anggreny \\ STBA-PIA, Medan, Sumatera Utara
}

\begin{abstract}
摘要
本文研究目的是想了解图示教学法对汉语词汇教学的应用, 同时也想了解卫理小学 汉语教师使用图示教学法进行汉语词汇教学中的原因。图示教学法是用图示表现事 物本质, 用图示表现抽象的逻辑推理过程, 复杂知识间的内在联系, 使简要的文字 起到画龙点睛的作用, 借图示助讲解, 目的是能够让学生们容易接受并理解所教的 知识, 引起学生学习兴趣。本研究使用文献研究法、观察法、访谈法来分析, 最后 得出图示教学法。研究结果表明, 图示教学法对学生学习汉语词汇的影响明显, 这 种教学法激发学生学习汉语的兴趣, 也使课堂教学更高效。这些都是卫理小学汉语 教师使用图示教学法对汉语词汇教学中的原因。
\end{abstract}

关联词：图示教学法; 汉语词汇; 教学; 应用 


\title{
JOURNAL OF LANGUAGE, LITERATURE, AND TEACHING
}

Vol. 1 No. 2, August 2019, pp. 42 - 49

Available online at:

\begin{abstract}
The purpose of this paper was to understand the application of graphic teaching methods to Chinese vocabulary teaching, and also to understand the reasons why Chinese teachers in Weili Elementary School used the graphic teaching method to teach Chinese vocabulary. The graphics teaching method was to express the essence of things by means of diagrams, to express the abstract logical reasoning process with illustrations, and the internal relationship between complex knowledge, so that the brief texts could play a finishing touch, and the purpose was to enable students to explain. They were easy to accept and understand the knowledge they teach and cause students to learn. This study used literature research methods, observation methods, interviews to analyze, and finally draws a graphic teaching method. The research results showed that the graphics teaching method had an obvious influence on students' learning Chinese vocabulary. This teaching method stimulated students' interest in learning Chinese and made classroom teaching more efficient. These were the reasons why Chinese teachers in Weili Elementary School used the graphic teaching method to teach Chinese vocabulary.
\end{abstract}

Keywords: graphic teaching method; Chinese vocabulary; teaching; application 


\title{
JOURNAL OF LANGUAGE, LITERATURE, AND TEACHING \\ Vol. 1 No. 2, August 2019, pp. 42 - 49 \\ Available online at: \\ http://www.jllte.stbapia.ac.id
}

\begin{abstract}
Pendahuluan
Bahasa adalah alat komunikasi yang berupa sistem lambang bunyi yang dihasilkan alat ucap manusia. Keraf dalam Smarapradipha (2005:1) mendefinisikan bahasa dalam dua pengertian, yaitu: 1.Bahasa sebagai alat komunikasi antara anggota masyarakat berupa simbol bunyi yang dihasilkan oleh alat ucap manusia. 2. Bahasa adalah sistem komunikasi yang mempergunakan simbol-simbol vokal (bunyi ujaran) yang bersifat arbitrer.

Melihat perkembangan China yang mampu mempengaruhi ekonomi dunia saat ini, bahasa Mandarin telah menjadi bahasa internasional ke-2 setelah bahasa Inggris. Dengan demikian, dalam pemenuhan kebutuhan kehidupan sehari-hari, misalnya dalam hubungan bisnis, studi, pariwisata dan perdagangan. Seiring dengan perkembangan China saat ini, banyak lembaga pendidikan yang sadar akan kebutuhan komunikasi bahasa asing khususnya bahasa Mandarin, sehingga banyak lembaga pendidikan atau sekolah mulai dari tingkat terendah sampai ke tingkat perguruan tinggi menawarkan pelajaran bahasa Mandarin sebagai pelajaran intra sekolah maupun ekstra sekolah.

Berhubung bahasa mandarin adalah bahasa asing yang sulit untuk dipelajari, dikarenakan bahasa mandarin memiliki kosakata yang beragam dan rumit, maka sangat dianjurkan belajar bahasa Mandarin hendaknya dimulai sejak kecil. Banyak cara dan berbagai media yang mampu mempercepat proses penyerapan dalam mempelajari bahasa Mandarin. Salah satunya adalah melalui media gambar. Diantara media pendidikan yang digunakan, gambar atau foto adalah media yang paling umum digunakan. Kàn (2011) dalam penelitiannya menunjukkan bahwa: "respon otak manusia terhadap informasi bahasa adalah yang paling lambat, penyampaian informasi dengan metode gambar respon yang nyata. Dengan mendengar hanya dapat mengingat 15\%, dengan melihat dapat meningkat menjadi 25\%, integrasi audiovisual dapat mencapai hasil sampai nilai $65 \%$. Ini menunjukan bahwa penggunaan gambar dalam pembelajaran bahasa mandarin memilki peran yang penting. Oleh karena itu, penulis tertarik melakukan penelitian tentang
\end{abstract}


JOURNAL OF LANGUAGE, LITERATURE, AND TEACHING

Vol. 1 No. 2, August 2019, pp. 42 - 49

Available online at:

STBADPIA

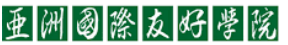

http://www.jllte.stbapia.ac.id

penggunaan media gambar dalam pembelajaran kosakata bahasa Mandarin di SD Perguruan Kristen Methodist Indonesia Pangkalan Berandan, dan untuk hal ini maka penulis memilih judul skripsi sebagai berikut: Penggunaan Media Gambar dalam Pembelajaran Kosakata Bahasa Mandarin di SD Perguruan Kristen Methodist Indonesia Pangkalan Berandan.

\section{Metode}

Penelitian ini menggunakan desain penelitian kualitatif deskriptif. Subjek dalam penelitian ini adalah guru bahasa Mandarin kelas 6 SD Perguruan Kristen Methodist Indonesia. Data dalam penelitian ini dikumpulkan dengan melakukan observasi langsung ke SD Perguruan Kristen Methodist Indonesia Pangkalan Berandan; dan melakukan wawancara terhadap guru Bahasa Mandarin kelas 6 SD Perguruan Kristen Methodist Indonesia Pangkalan Berandan.

\section{Hasil}

\section{Cara Penggunaan Media Gamvbar dalam Pembelajaran Kosakata Bahasa Mandarin oleh Guru SD di SD Perguruan Kristen Methodist Indonesia}

Dari hasil analisis data observasi terhadap guru yang dilakukan oleh penulis adalah sebagai berikut:

\section{Data 1}

1. Guru mengawali proses belajar-mengajar dengan mengucapkan salam kepada murid.

2. Guru mengabsen kehadiran murid.

3. Guru membimbing murid untuk memperhatikan materi yang akan di ajarkan.

4. Guru menjelaskan 20 kosakata bahasa Mandarin, sambil memegang gambar dari masing-masing 20 kosakata tersebut.

\section{Data 2}

1. Guru mengawali proses belajar mengajar dengan mengucapkan salam kepada siswa.

2. Guru mengabsen kehadiran siswa.

3. Guru membimbing siswa untuk memperhatikan materi yang akan di ajarkan.

4. Guru menjelaskan 20 kosakata bahasa Mandarin, sambil memegang gambar dari masing-masing 20 kosakata tersebut. 


\section{JOURNAL OF LANGUAGE, LITERATURE, AND TEACHING}

Vol. 1 No. 2, August 2019, pp. 42 - 49

Available online at:

5. Guru memberikan pertanyaan beberapa kali dengan menanyakan : "Gambar apakah ini?" dan dijawab oleh murid secara bersama dengan memberikan jawaban yang benar dalam bahasa Mandarin.

6. Kemudian guru memberikan pertanyaan kembali, dimana guru memperlihatkan gambar dan bertanya : "Siapakah yang bisa menuliskan jawabannya di papan tulis berupa tulisan Mandarin?". Murid menunjuk tangan tangan dan menyebutkan nama gambar lalu menuliskannya ke papan tulis dalam bahsa Mandarin dengan benar.

\section{Alasan Mengapa Guru SD Perguruan Kristen Methodist Indonesia Pangkalan Berandan Menggunakan Gambar sebagai Media Pembelajaran}

Berikut ini penulis memberi penjelasan tentang hasil wawancara terhadap seorang guru

bahasa Mandarin di sekolah tersebut:

\section{Data 3}

P: Apakah pendapat ibu tentang penggunaan media gambar dalam pembelajaran kosakata bahasa Mandarin?

G: Penggunaan media gambar dalam pembelajaran kosakata bahasa Mandarin sangat baik, karena dapat memperlancar proses penyampaian materi yang saya ajarkan kepada murid-murid, dan murid-murid juga memberi perhatian penuh pada saat saya menjelaskan materi pelajaran dengan menggunakan media gambar.

P: Bagaimana kondisi di dalam ruangan kelas pada saat ibu menggunakan media gambar dalam proses belajar?

G: Pada saat saya menerangkan materi pelajaran kepada murid dengan menggunakan media gambar, kondisi diruangan cukup tenang, karena murid-murid memperhatikan dengan saksama.

P: Bagaimana respon murid terhadap penggunaan media gambar dalam pembelajaran kosakata bahasa Mandarin?

G: Respon murid terhadap penggunaan media gambar dalam proses belajar cukup baik, mereka lebih mudah mengerti materi pelajaran yang saya sampaikan melalui media gambar yang saya sediakan, misalnya mereka jadi lebih cepat mengerti sehingga mereka menjadi semangat untuk lanjut belajar, tidak ada yang bermalasmalasan, mereka merasa senang dan tertarik terhadap materi pelajaran yang sedang saya ajarkan. Selain itu, murid juga terlihat sangat senang dari cara mereka memperhatikan saya di saat saya mengajar, mereka menulis catatan berisi materi pelajaran yang saya ajarkan dengan semangat sampai catatan mereka 


\section{JOURNAL OF LANGUAGE, LITERATURE, AND TEACHING}

Vol. 1 No. 2, August 2019, pp. 42 - 49

Available online at:

http://www.jllte.stbapia.ac.id

selesai, dan sesekali bertanya jika ada yang merasa kurang jelas. Mereka juga sangat antusias ingin menjawab disaat sayamengadakan kuis tanya jawab berdasarkan materi pelajaran yang sayaajarkan secara spontan sesekali sebelum pelajaran berakhir.

P: Apakah penggunaan media gambar dalam pembelajaran kosakata bahasa Mandarin dapat membantu? Jelaskan!

G: Iya, sangat membantu bagi saya maupun bagi murid, karena dengan menggunakan media gambar dalam materi pelajaran kosakata bahasa Mandarin lebih muda untuk disampaikan, maksudnya lebih singkat dan jelas. Kalau buat murid juga membantu, karena mereka lebih mudah untuk menerima materi pelajaran dan lebih mudah mengingat materi pelajaran yang dipelajari, selain itu mereka juga lebih bersemangat setiap kali belajar, setiap kali menulis catatan setelah saya terangkan materi pelajarannya menggunakan gambar, bahkan bersemangat dalam menjawab kuis yang saya adakan sesekali secara spontan.

P: Apa sajakah manfaat yang muncul dari penggunaan media gambar dalam pembelajaran kosakata bahasa Mandarin tersebut? Jelaskan!

G: Ya lumayan banyak, misalnya murid jadi lebih mudah menerima materi pelajaran yang saya sampaikan, otomatis hal ini dapat mempersingkat waktu sehingga dapat membahas lebih banyak materi pelajaran dari yang seharusnya. Manfaat lain, dapat membantu saya dalam menyampaikan materi pelajaran, karena media gambar itu kan bisajadi ilustrasi dari arti kosakata yang saya jelaskan.

P: Apakah ibu merasa puas dengan penggunaan media gambar dalam pembelajaran kosakata bahasa Mandarin tersebut?

$\mathrm{J}$ : Ya, puas. Karena banyak manfaatnya.

Dari hasil wawancara terhadap guru bahasa Mandarin SD Perguruan Kristen Methodist Indonesia Pangkalan Berandan di atas, ditemukan bahwa murid-murid tertarik atau cenderung lebih bersemangat dalam proses belajar kosakata bahasa Mandarin dengan menggunakan gambar sebagai media pembelajarannya.

Hasil penelitian berdasarkan observasi yang penulis lakukan terhadap seorang guru bahasa Mandarin di SD Perguruan Kristen Methodist Indonesia Pangkalan Berandan yaitu terlihat bahwa cara guru mengajar murid dapat dilakukan dengan baik karena guru tampak berusaha membuat murid berpartisipasi di dalam kegiatan belajar, meskipun guru tersebut menggunakan gambar sebagai salah satu media pembelajaran kosakata bahasa Mandarin.

Berdasarkan hasil wawancara ditemukan penulis bahwa ternyata mengapa media gambar digunakan adalah karena murid-murid dapat memperhatikan materi pelajaran dengan seksama, media gambar juga dapat membuat murid lebih mudah mengerti dan bersemangat untuk melanjutkan pelajaran. Murid dapat tertarik terhadap materi pelajaran 


\section{JOURNAL OF LANGUAGE, LITERATURE, AND TEACHING \\ Vol. 1 No. 2, August 2019, pp. 42 - 49 \\ Available online at: \\ http://www.jllte.stbapia.ac.id}

yang diajarkan dengan gambar yang digunakan sebagai media pembelajarannya. Selain itu, guru dapat terbantu dalam menyampaikan materi pelajaran kosakata bahasa Mandarin tersebut, karena media gambar dapat memperjelas materi pembelajaran dan menjadi ilustrasi dari arti setiap kosakata yang dipelajari dimana proses pembelajaran bisa menjadi variatif yang tidak membosankan.

\section{Pembahasan}

Menurut Girendha (2012), pembelajaran kosakata dapat dilaksanakan dengan menggunakan media pembelajaran karena media pembelajaran merupakan alat bantu yang dapat membantu siswa dalam memahami materi pelajaran yang disampaikan oleh guru. Dalam hal ini, dapat dibuktikan bahwa guru dengan cara menggunakan gambar sebagai media pembelajaran di SD Perguruan Kristen Methodist Indonesia dapat melakukan hal tersebut di atas sebagaimana yang telah ditemukan oleh penulis dalam penelitiannya.

Menurut Arsyad (2012), manfaat praktis media gambar dalam proses pembelajaran Bahasa Mandarin antara lain adalah bahwa media gambar dapat memperjelas penyajian pesan dan informasi sehingga dapat memperlancar proses dan meningkatkan hasil belajar, media gambar dapat meningkatkan dan mengarahkan perhatian anak sehingga dapat menimbulkan motivasi belajar, misalnya seperti yang dapat dilihat dari semangat mereka belajar ketika penulis mewawancarai guru bahasa Mandarin di sekolah tersebut.

Selain itu, menurut Lie (2007:79) media gambar adalah alat, metode dan teknik yang digunakan dalam rangka lebih mengefektifkan komunikasi dan interaksi antara guru dan murid dalam proses pendidikan dan pengajaran di sekolah. Hal yang demikian jugalah yang ditemukan dari hasil wawancara penulis terhadap guru bahasa Mandarin SD Perguruan Kristen Methodist Indonesia.

\section{Daftar Pustaka}

Arsyad, Azhar. 2010. Fungsi dan Nilai Media Gambar. Ian43.wordpress.com /2010/12/17/fungsi-dan-nilai-media-gambar/. Diakses pada tanggal 28 Oktober 2014.

Girendha, Philip. 2012. Penerapan Media Circular Cards Dalam Pembelajaran Kosakata Bahsa Jerman Pada Kelas X SMA Negri 6 Malang. Malang: Universitas Negri Malang. 
JOURNAL OF LANGUAGE, LITERATURE, AND TEACHING

Vol. 1 No. 2, August 2019, pp. 42 - 49

Available online at:

STBADPIA

http://www.jllte.stbapia.ac.id

Kàn, Tīngtīng. 2011. Duìwài Hànyŭ Jiāoxué Túshì Jiāoxuéfã Yánjiū. Bohai University.

Smarapradipha, Galih. 2005. Sepuluh Pengertian Bahasa Menurut Para Ahli. Bogor. http://Wismasastra.wordpress.com/2009/05/25/apa-bahasa-itu-sepuluh-penge rtian-menurut-para-ahli/. Diakses pada tanggal 20 Februari 2014. 